\title{
Beta-3 Adrenergic Receptor
}

National Cancer Institute

\section{Source}

National Cancer Institute. Beta-3 Adrenergic Receptor. NCI Thesaurus. Code C126973.

Beta-3 adrenergic receptor ( $408 \mathrm{aa}, \sim 44 \mathrm{kDa}$ ) is encoded by the human ADRB3 gene.

This protein plays a role in $\mathrm{G}$ protein-coupled receptor signaling, lipolysis, and thermogenesis. 